challenge is the universally recognised and accepted method of diagnosis for EIB in elite athletes. What still needs to be more clearly determined is the exact level of fall of $\mathrm{FEV}_{1}$ in response to challenge in elite athletes which represents an abnormal response.

Thorax 2006;61:94-96.

doi: 10.1136/thx.2005.049031

\section{Authors' affiliations}

K Holzer, Department of Respiratory

Medicine, Royal Melbourne Hospital and

University of Melbourne, Parkville 3050,

Australia

J A Douglass, Department of Allergy,

Immunology and Respiratory Medicine, Alfred

Hospital and Monash University, Melbourne,

Victoria 3004, Australia

Correspondence to: A Professor J A Douglass, Department of Allergy, Immunology and Respiratory Medicine, Alfred Hospital and

Monash University, Melbourne, Victoria 3004,

Australia; j.douglass@alfred.org.au

Funding: none.

Competing interests: none.

\section{REFERENCES}

1 International Olympic Committee. http:// multimedia.olympic.org/pdf/en_report_981.pdf (accessed 28 October 2005).

2 Anderson SD. Exercise-induced asthma. In: Middleton E, Reed C, Ellis E, et al. Allergy: principles and practice. 4th ed. St Louis: CV Mosby, 1993:1343-67.

3 Anderson SD. Exercise-induced asthma. In: Carlsen $\mathrm{KH}$, Ibsen TB, eds. Exercise-induced asthma and sports in asthma. Copenhagen: Munksgaard, 1999:11-5.

4 Rundell KW, Im J, Mayers LB, et al. Self-reported symptoms and exercise-induced asthma in the elite athlete. Med Sci Sports Exerc 2001;33:208-13.

5 Holzer K, Anderson SD, Douglass J. Exercise in elite summer athletes: challenges for diagnosis. J Allergy Clin Immunol 2002;110:374-80

6 Phillips YY, Jaeger JJ, Laube BL, et al. Eucapnic voluntary hyperventilation of compressed gas mixture. A simple system for bronchial challenge by respiratory heat loss. Am Rev Respir Dis 1985;131:31-5.

7 Hurwitz KM, Argyros GJ, Roach JM, et al. Interpretation of eucapnic voluntary hyperventilation in the diagnosis of asthma. Chest 1995; 108: 1240-5.

8 Eliasson $\mathbf{A H}$, Phillips YY, Rajagopal KR, et al. Sensitivity and specificity of bronchial provocation testing. An evaluation of four techniques in exercise-induced bronchospasm. Chest $1992 \cdot 102 \cdot 347-55$
9 Mannix ET, Manfredi F, Farber MO. A comparison of two challenge tests for identifying exercise-induced bronchospasm in figure skaters. Chest 1999.115:649-53.

10 Rundell KW, Anderson SD, Spiering BA, et al. Field exercise vs laboratory eucapnic voluntary hyperventilation to identify airway hyperresponsiveness in elite cold weather athletes. Chest 2004; 125:909-15.

11 Riedler J, Reade T, Dalton M, et al. Hypertonic saline challenge in an epidemiologic survey of asthma in children. Am J Respir Crit Care Med 1994;150:1632-9.

12 Brannan JD, Koskela H, Anderson SD, et al. Responsiveness to mannitol in asthmatic subjects with exercise- and hyperventilation-induced asthma. Am J Respir Crit Care Med 1998;158:1120-6.

13 Holzer K, Anderson SD, Chan HK, et al. Mannitol as a challenge test to identify exercise-induced bronchoconstriction in elite athletes. Am J Respir Crit Care Med 2003;167:534-7.

14 Dickinson JW, Whyte GP, McConnell AK, et al. Mid-expiratory flow versus FEV measurements in the diagnosis of exercise induced asthma in elite athletes. Thorax 2006;61:111-4.

15 Custovic A, Arifhodzic N, Robinson A, et al Exercise testing revisited. The response to exercise in normal and atopic children. Chest 1994; 105: 1127-32.

16 Sue-Chu M, Larsson L, Moen T, et al. Bronchoscopy and bronchoalveolar lavage findings in cross-country skiers with and without "ski asthma". Eur Respir J 1999; 13:626-32.

\title{
Why does airway inflammation persist after the smoking stops?
}

\section{J C Hogg}

\section{Important new observations on the behaviour of $\mathrm{T}$ lymphocytes and plasma cells following prolonged smoking cessation in patients with COPD}

$\mathrm{T}$ he toxic gases and particles generated in tobacco smoke come into contact with lung tissues each time a puff of smoke is inhaled, and this tissue injury recurs in a cyclic fashion as each cigarette is smoked. A 20 pack year smoking history indicates that the subject's lungs have received 20 of these short cyclic exposures per day for a cumulative total of 7300 exposures per year and 146000 exposures over the lifetime of their smoking habit. This complex pattern of acute upon chronic inhalation injury reduces the innate defences of the lung by interfering with mucociliary clearance, ${ }^{1}$ diminishing the inflammatory cytokine response to other stimuli, ${ }^{2}$ and disrupting the epithelial barrier. ${ }^{3}{ }^{4}$ The tissue damaged by the smoke becomes infiltrated with innate and adaptive inflammatory immune cells and, even though tobacco smoke exposure may suppress the immune response, ${ }^{5}$ the lymphoid cells collect to form the follicles with germinal centres that document the presence of the adaptive immune response. ${ }^{6}$ The antigens that drive this immune response have not been clearly identified, but both microbial antigens that accumulate as a result of colonisation and infection of the lower respiratory tract, and possibly autoantigens created within injured lung tissue, have been implicated. ${ }^{6-8}$

The classic longitudinal study of chronic bronchitis and emphysema conducted by Fletcher and associates in the late 1950s and 1960s established that only $20-25 \%$ of smokers develop airflow limitation. ${ }^{9}$ These investigators also observed beneficial effects from stopping smoking that have been confirmed in early stage (GOLD 1 and 2 ) disease by a randomised controlled trial. ${ }^{10}$ The fact that COPD is limited to a susceptible minority of smokers, ${ }^{9}$ and those that successfully stop smoking both slow their rate of decline in forced expiratory volume in 1 second $\left(\mathrm{FEV}_{1}\right)$ and delay their death, ${ }^{910}$ is not easy to reconcile with cross sectional observations on lung tissue pathology where the chronic inflammatory response that is thought to drive the process is observed in everyone that smokes and seems to persist long after the smoking has stopped. ${ }^{6}{ }^{11}{ }^{12}$ Although this discrepancy has been partially reconciled by observations indicating that the response to tobacco smoke is amplified in the minority of smokers that develop COPD, ${ }^{13}{ }^{14}$ the precise mechanisms for either the amplification step found in association with the group that develop COPD or the persistence of the inflammatory immune response following the removal of the smoking stimulus remain to be clarified.

Lapperre and colleagues ${ }^{15}$ address this problem in this issue of Thorax in a study of 114 patients in GOLD stages 2 and 3 COPD who were not receiving either inhaled or oral steroids at the time of the study. There were 99 men, and 42 had quit smoking for a median time of 3.5 years. They found that, as a group, the ex-smokers had higher numbers of CD4+ lymphocytes and plasma cells than current smokers while there was no difference in the numbers of neutrophils, macrophages, or CD8+ cells 
between the groups. However, when they divided the ex-smokers into short term (stopped $<3.5$ years) and longer term (stopped $>3.5$ years) ex-smokers, those who had stopped the longest had lower CD8+ $\mathrm{T}$ cell numbers and increased plasma cell counts. Based on these observations, they propose that $\mathrm{T}$ lymphocyte and plasma cell numbers respond to current smoking status whereas other inflammatory cells do not, and suggest that the presence of either an ongoing microbial stimulus or the development of autoimmune disease drives this lymphocyte response. These new and important observations on the behaviour of $\mathrm{T}$ lymphocytes and plasma cells following prolonged smoking cessation deserve further attention for several reasons.

Although Fletcher et al thought that smoking cessation reduced the rate of decline in expiratory airflow with age even in the late stages of the disease, the only randomised controlled trial showing that the rate of decline in $\mathrm{FEV}_{1}$ is slowed by stopping smoking was conducted in relatively young patients (mean age 48 years) with mild (GOLD stage 1 and 2) disease. ${ }^{10}$ What happens to the rate of decline when smoking cessation is the only intervention in older subjects with more severe disease has not been studied in a randomised controlled fashion and could be quite different because the pathology in the early stages of COPD might be easier to reverse than that found after COPD has progressed. A cross sectional study of small airway pathology across the GOLD categories of COPD has shown that the decline in
$\mathrm{FEV}_{1}$ is more closely associated with a repair and remodelling process that thickens the airway wall than with the extent and severity of the inflammatory immune response. ${ }^{6}$ It also showed that there is a sharp increase in the adaptive component of the inflammatory immune response in the severe (GOLD stage 3 ) and very severe (GOLD stage 4) categories of COPD where the airway wall thickening was the greatest. ${ }^{6}$ Laperre and colleagues provide new insight into this problem by providing data indicating that the lymphocytes that control the adaptive response are driven by antigen following prolonged smoking cessation. These observations should stimulate those who are interested in this problem to conduct the experiments required to determine whether microbial or autoantigens drive the adaptive immune response in the late stages of COPD, and to determine what links can be found between this adaptive immune inflammatory response found in the late stages of COPD and the thickening of the airway wall by the repair and remodelling process.

Thorax 2006;61:96-97.

doi: $10.1136 /$ thx.2005.049502

Correspondence to: Professor J C Hogg, McDonald Research Laboratories, St Paul's Hospital, Vancouver, Canada, V6Z 1Y6: jhogg@mrl.ubc.ca

\section{REFERENCES}

1 Ericsson $\mathrm{CH}$, Svartengren $\mathrm{K}$, Svartengren $\mathrm{M}$ et al. Repeatability of airway deposition and tracheobronchial clearance over three day in chronic bronchitis. Eur Respir $\mathrm{J}$ 1995:8:1886-93.
2 Laan M, Bozinovski S, Anderson GP. Cigarette smoke inhibits lipopolysaccharide-induced production of inflammatory cytokines by suppressing the activation of activator protein- 1 in bronchial epithelial cells. J Immunol 2004;173:4164-70.

3 Simani AS, Inove S, Hogg JC. Penetration of respiratory epithelium of guinea pigs following exposure to cigarette smoke. Lab Invest 1974;31:75.

4 Jones JG, Minty BD, Lawler P, et al. Increased alveolar epithelial permeability in cigarette smokers. Lancet 1980;1:66-8.

5 Drannic AG, Pouladi MA, Robbins CS et al. Impact of cigarette smoke on clearance and inflammation after Pseudomonas aeruginosa infection. Am J Respir Crit Care Med 2004; 170:1164-71

6 Hogg JC, Chu F, Utokparch S, et al. The nature of small airway obstruction in chronic obstructive lung disease. N Engl J Med 2004;350:2645-53.

7 Sethi S. Bacterial infection and the pathogenesis of COPD. Chest 2000;117(5 Suppl 1):286-91S.

8 Taraseviriene-Stewart L, Scerbavicus R, Choe KH, et al. An animal model of autoimmune emphysema. Am J Respir Crit Care Med 2005; 171:734-42.

9 Fletcher C, Peto R, Tinker C, et al. The natural history of chronic bronchitis and emphysema. Oxford: Oxford University Press, 1976:93.

10 Anthonisen NR, Skeanes MA, Wise RA, et al. The effect of smoking cessation intervention on 14.5 year mortality. Ann Intern Med 2005; 142:233-8.

11 Wright JL, Lawson LM, Pare PD, et al. Morphology of peripheral airways in current smokers and ex-smokers. Am Rev Respir Dis 1983; 127:474-7.

12 Rutgers SR, Postma DS, ten Haken NH, et al. Ongoing airway inflammation in patients with COPD who do not currently smoke. Thorax 2000;55:12-8.

13 Retamales I, Elliott $M$, Meshi B, et al. Amplification of inflammation in emphysema and its association with latent adenoviral infection. Am J Respir Crit Care Med 2001:164:469-73.

14 Keatings VM, Collins PD, Scott DM, et al. Differences in interleukin- 8 and tumour necrosis factor-alpha in induced sputum from patients with chronic obstructive pulmonary disease or asthma. Am J Respir Crit Care Med 1996;153:530-4

15 Lapperre TS, Postma DG, Grosman JB, et al. Relation between duration of smoking cessation and bronchial inflammation in COPD. Thorax 2005:61:115-21. 